DOI: https://doi.org/10.31933/jimt.v2i4 Received: 3 Januari 2021, Revised: 25 Februari 2021, Publish: 13 Maret 2021

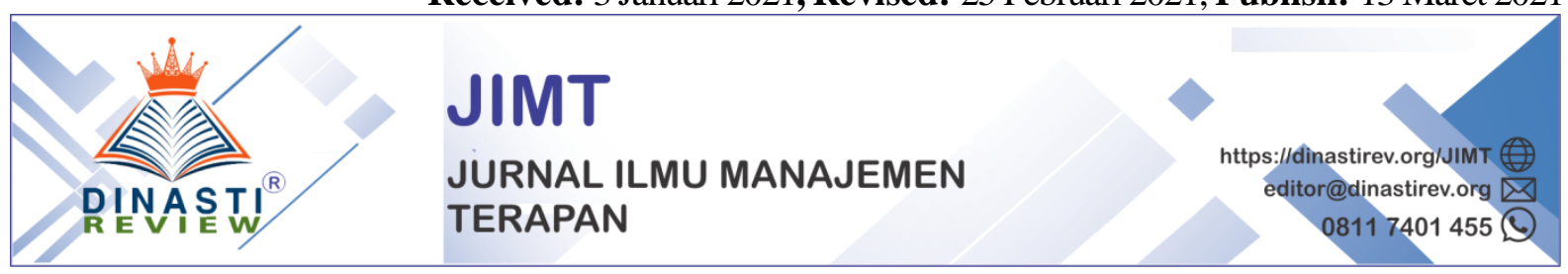

\title{
FAKTOR-FAKTOR YANG MEMPENGARUHI PERSAINGAN DAN PERTUMBUHAN PASAR: PEMIMPIN, PESAING, PENGIKUT, NICHER (SUATU LITERATURE REVIEW)
}

\author{
Rizal Agung W' ${ }^{\mathbf{1}}$, Gabriel Yudhistira $\mathbf{H}^{\mathbf{2}}$, Rifqi Aziz ${ }^{\mathbf{3}}$ \\ ${ }^{1}$ Mahasiswa Magister Management UMB, email: rizal@plne.co.id \\ ${ }^{2}$ Mahasiswa Magister Management UMB, email: gyudhistirahf@gmail.com \\ ${ }^{3}$ Mahasiswa Magister Management UMB, email: rifqiazizzz@gmail.com
}

\section{Corresponding Author: Rizal Agung W}

\begin{abstract}
Abstrak: Dalam proses bisnis yang ada, bagaimana organisasi dapat mencapai posisi sebagai pemimpin pasar untuk kategori produk tertentu seringkali banyak perusahaan yang harus mengawalinya dari market challenger atau market follower bahkan nicher. Literature Review ini menguji pengaruh moderasi intensitas kompetisi dan pertumbuhan pasar terhadap hubungan pemimpin pasar, persaing, pengikut dan nicher. Bahwa Keempatnya dapat memberikan dampak yang besar bagi masa depan organisasi. Dalam literature ini penulis akan mengulas persaingan dan pertumbuhan pasar baik pada pasar domestik maupun internasional. Berbagai pemimpin pasar, persaing, pengikut dan nicher telah ditemukan di beberapa penelitian tentang kaitannya dengan persaingan dan pertumbuhan pasar. Perkembangan pasar akan terus berubah sehingga perlu dilakukan strategi pemasaran untuk mempertahan posisi pasar organisasi.
\end{abstract}

Kata Kunci: persaingan pasar, pertumbuhan pasar, pemimpin, Pesaing, Pengikut, Nicher

\section{PENDAHULUAN}

Situasi pasar akan berubah mengikuti perkembangan strategi perusahaan yang dilakukan. Persaingan dan pertumbuhan pasar sangat mempengaruh organisasi dalam menjalankan bisnisnya. Menjelaskan bahwa setiap posisi persaingan memerlukan strategi bersaing yang berbeda pula. Perusahaan dalam posisi persaingan yang sama harus menggunakan pemahaman ini untu merancang penawaran pasar yang memberikan nilai lebih daripada penawaran pesaingnya menurut Kotler (2010). Tujuan dari penulisan "Literature Review Paper" ini adalah untuk lebih mamahami materi pada perkuliahan "STRATEGIC MARKETTING MANAGEMEN", sehingga dapat di implementasikan pada penulisan artikel ilmiah atau Tesis. "Literature Review Paper" ini mengkaji teori-teori dan artikel-artikel ilmiah dari jurnal-jurnal bereputasi yang bekaitan dengan tema-tema dari Rencana Pembelajaran Semester (RPS) yang berbasis Outcome Base Education(OBE) untuk menghasilkan kerangka konseptual (conceptual framework) untuk riset selanjutnya (tesis). 
Secara rinci tujuan dari penulisan "Literature Review Paper" ini adalah mengetahui pengaruh atau hubungan antara variabel exogen (pemimpin pasar, pengikut pasar, dan nicher) terhadap variabel endogen (persaingan \& pertumbuhan pasar):

1) pengaruh atau hubungan pemimpin pasar terhadap persaingan pasar

2) pengaruh atau hubungan penantang pasar terhadap persaingan pasar

3) pengaruh atau hubungan pengikut pasar terhadap persaingan pasar

4) pengaruh atau hubungan nicher terhadap persaingan pasar

5) pengaruh atau hubungan pemimpin pasar terhadap pertumbuhan pasar

6) pengaruh atau hubungan penantang pasar terhadap pertumbuhan pasar

7) pengaruh atau hubungan pengikut pasar terhadap pertumbuhan pasar

8) pengaruh atau hubungan nicher terhadap pertumbuhan pasar

9) pengaruh atau hubungan persaingan pasar terhadap pertumbuhan pasar

\section{KAJIAN TEORI}

\section{Teori kompetisi}

Menurut Adam Smith dalam The Wealth of Nations (1776) Persaingan akan mendorong alokasi faktor produksi ke arah penggunaan yang paling bernilai tinggi dan efisien. Proses tersebut sering disebut tangan tak terlihat (invisible hand). Dalam teori mikroekonomi, persaingan dalam suatu pasar dibedakan menjadi persaingan sempurna dan persaingan tidak sempurna. Pasar yang tidak memiliki persaingan disebut monopoli. Adanya persaingan menyebabkan perusahaan komersial untuk mengembangkan produk, teknologi dan jasa, sehingga menyebabkan lebih banyak pilihan, menghasilkan produk yang lebih baik dan harga yang lebih rendah

Menurut Marbun (2003) Pengertian persaingan usaha atau bisnis adalah usaha dari dua pihak/lebih perusahaan yang masing-masing bergiat memperoleh pesanan dengan menawarkan harga/syarat yang paling menguntungkan. Persaingan adalah ketika organisasi atau perorangan berlomba untuk mencapai tujuan yang diinginkan seperti konsumen, pangsa pasar, peringkat survei, atau sumber daya yang dibutuhkan.

Persaingan usaha dilakukan untuk merebut hati konsumen. Para pelaku usaha berusaha menawarkan produk dan jasa yang menarik, baik dari segi harga, kualitas dan pelayanan. Kombinasi ketiga faktor tersebut untuk memenangkan persaingan merebut hati para konsumen dapat diperoleh melalui inovasi, penerapan teknologi yang tepat, serta kemampuan manajerial untuk mengarahkan sumber daya perusahaan dalam memenangkan persaingan.

Menurut Kotler (2010) Menjelaskan bahwa setiap posisi persaingan memerlukan strategi bersaing yang berbeda pula. Perusahaan dalam posisi persaingan yang sama harus menggunakan pemahaman ini untuk merancang penawaran pasar yang memberikan nilai lebih daripada penawaran pesaingnya.

Michael Treacy dan Fred Wiersema (dalam Kotler, 2010) Memberikan tiga strategi bersaing lain yang disebut dengan value disciplines, di mana perusahaan memperoleh posisi yang unggul dengan memberikan nilai yang lebih besar kepada konsumen. Ketiga strategi tersebut yaitu kesempurnaan operasional, keintiman pelanggan, dan kepemimpinan produk. 


\section{Teori pertumbuhan pasar}

Fungsi terpenting dalam pemasaran adalah pertumbuhan pasardalam penjualan dan pendapatan perusahaan.

Menurut Phil dan Milton Kotler Menekankan 8 strategi pertumbuhan, yakni sebagai berikut:

1) Tumbuh dengan membangun pangsa pasar

2) Tumbuh dengan mengembangkan konsumen dan para pemegang saham yang berkomitmen

3) Tumbuh dengan membangun brand yang kuat

4) Tumbuh dengan menginovasikan produk, layanan, dan pengalaman baru

5) Tumbuh dengan ekspansi global

6) Tumbuh dengan akuisisi, merger, dan kerjasama

7) Tumbuh dengan membangun reputasi yang luar biasa untuk tanggung jawab sosial

8) Tumbuh dengan kemitraan bisnis bersama pemerintah dan lembaga swadaya masyarakat

Banyak strategi pertumbuhan yang tersedia untuk perusahaan, beberapa peluang terbaik datang dari pertumbuhan inti yang berfokus pada produk dan pasar yang telah ada dan sukses. Seringkali kemampuan unik suatu perusahaan tidak efektif dalam menerjemahkan sebuah industri baru. Pertumbuhan inti dapat menjadi alternatif yang berisiko rendah daripada melakukan ekspansi ke kategori produk baru. Hal ini memperkuat identitas merek sebagai sumber otoritas dan kredibilitas serta dapat menghasilkan skala ekonomi. Melalui peningkatan pendapatan dan biaya yang lebih rendah, pertumbuhan inti juga dapat menghasilkan laba yang lebih besar.

Menurut David Taylor Tiga strategi utama adalah sebagai berikut:

1) Menciptakan inti dari brand dengan se-khas mungkin

2) Mendorong distribusi melalui tempat yang baru maupun yang sudah ada

3) Menawarkan produk inti dengan versi terbaru

Banyak perusahaan yang mencari kesuksesan dengan berfokus pada bisnis inti. Namun strategi pertumbuhan tidak selalu baik. Fokus pada bisnis inti bukan berarti melupakan peluang pasar baru, namun tetap saja bisnis inti tidak dapat hanya sekedar diperluas.

Menurut Alberto D. Hanani (2009) "Secara umum strategi pertumbuhan (growth strategy) perusahaan terbagi menjadi 3 (tiga) kategori. Pertama adalah strategi M\&A (Mergers \& Acquisitions). Kedua adalah strategi pertumbuhan organik melalui pengembangan pangsa pasar (Market Share). Ketiga adalah strategi pertumbuhan organik melalui pengembangan portfolio (baik portfolio pasar mau pun portfolio produk)". Hanani juga mengungkapkan "Berdasarkan sebuah studi yang dilakukan McKinsey \& Co. beberapa tahun terakhir, ditemukan bahwa pengembangan portfolio pasar merupakan strategi pertumbuhan yang paling efektif bagi banyak perusahaan (member kontribusi bagi sekitar 50\% responden). Sementara itu, strategi M\&A menduduki peringkat kedua (yang member kontribusi signifikan kepada sekitar 30\% responden), dan strategi pengembangan market share memberi kontribusi kepada $20 \%$ responden". 


\section{Pemimpin pasar (Market Leader)}

Dalam pemasaran dikenal dengan namanya persaingan, namun terkadang banyak pelaku pasar sendiri yang tidak mengerti atau belum bias mengidentifikasi apa itu sebenarnya yang dimaksud dengan persaingan. Perusahaan yang berhasil selalu berusaha mengenali pesaingnya sebaik mungkin seperti yang dilakukannya terhadap para konsumen. Analisis dan situasi persaingan akan membantu manajemen untuk memutuskan di mana akan bersaing dan bagaimana menentukan posisi menghadapi pesaingnya pada setiap pasar sasaran.

Berdasarkan perbedaan karakteristik perusahaan, telah mengklasifikasikannya kedalam empat posisi persaingan menurutu Kotler dan Amstrong (2010) yaitu:

1. Pemimpin Pasar (Market Leader)

2. Penantang Pasar (Market Challenger)

3. Pengikut Pasar (Market Follower)

4. Relung Pasar (Market Niche)

Perusahaan yang diakui oleh industri yang bersangkutan sebagai pemimpin. Karakteristik dari pemimpin pasar adalah:

1. Memiliki pangsa pasar yang terbesar (40\%) dalam pasar produk yang relevan.

2. Lebih unggul dari perusahaan lain dalam hal pengenalan produk baru, perubahan harga, cakupan saluran distribusi, danintensitas promosi.

3. Merupakan pusat orientasi para pesaing (diserang, ditiru, atau dijauhi).

Memberikan pengertian dari Market Leader tersebut adalah sebagai berikut: Pemimpin pasar (Market Leader) adalah perusahaan yang diakui oleh industri yang bersangkutan sebagai pemimpin menurut Tjiptono (2002:303). Perusahaan yang menduduki posisi sebagai pemimpin pasar mempunyai karakteristik sebagai berikut:

1. Memiliki pangsa pasar yang terbesar $(40 \%)$ dalam pasar produk yang relevan.

2. Lebih unggul dari perusahaan lain dalam hal pengenalan produk baru, perubahan harga, cakupan saluran distribusi dan intensitas promosi.

3. Merupakan pusat orientasi para pesaing (diserang, ditiru, atau dijauhi)

Menurut pengamat pemasaraan dari IBII, Hendrawan Supratikno. Kemampuan bertahan ini bisa ditempuh melalui beberapa cara sebagai berikut:

1. Mereka bisa melakukan predatory pricing terhadap musuh. Misalnya dengan membanting harga. Memang strategi price war biasanya sulit diikuti pesaing yang lebih kecil.

2. Non-price predatory conduct. Dalam langkah ini, mereka tidak langsung menurunkan harga. Tetapi efek yang ditimbulkan sama dengan perang harga. Ini banyak dilakukan oleh merk-merk rokok besar yang membeli tembakau dengan harga tinggi dari petani ketika panen tembakau. Dampaknya, pemain lain yang lebih kecil sulit untuk mendapatkan bahan baku. Termasuk pada langkah ini, adalah menguasai spot-spot iklan di berbagai tempat, seperti memasang billboard di tempat-tempat strategis.

3. Strategi entry deterrence, yaitu membuat pesaing secara strategis tidak bias bergerak dari posisinya saat ini. Pesaing dibiarkan hidup tetapi dikunci atau di tawan di posisinya. 
Persaingan yang makin ketat di seluruh dunia beberapa tahun terakhir ini telah memicu perhatian manajemen pada model perang militer, seperti diuraikan dalam tulisan Sun Tzu, Muhashi, von Clausewitz, dan Liddel-Hart. Perusahaan yang unggul, seperti negara yang unggul, dianjurkan untuk melindungi kepentingan dengan strategi seperti "memimpin saat terjepit", "pembalasan tegas", "perang terbatas", respon tertahap", "diplomasi kekerasan", dan "system ancaman". Ada enam strategi pertahanan yang dapat digunakan perusahaan yang dominan yaitu: pertahanan posisi, pertahanan rusuk, pertahanan mendahului, pertahanan serangan balik, pertahanan bergerak, pertahanan mundur.

\section{Penantang Pasar (Market Challenger)}

Berdasarkan perbedaan karakteristik perusahaan, telah mengklasifikasikannya posisi persaingan meenurut Kotler dan Amstrong (2010). Perusahaan 'runner-up' yang secara konstan mencoba memperbesar pangsa pasar mereka, yang dalam usaha tersebut mereka berhadapan secara terbuka dan langsung dengan pemimpin pasar.

Karakteristik penantang pasar adalah:

1) Biasanya merupakan perusahaan besar dipandang dari sudut volume penjualan dan laba (pangsa pasarnya $\pm 30 \%$ ).

2) Selalu berupaya menemukan kelemahan pihak pemimpin pasar atau perusahaan lainnya, dan kemudian menyerangnya baik secara langsung ataupun tidak langsung.

3) Penantang pasar biasanya juga memusatkan upaya mereka pada tindakan mengambil alih perusahaan-perusahaan yang lemah.

Strategi Penantang Pasar (market challenger) Adalah strategi yang biasanya dilakukan oleh perusahaan-perusahaan yang terletak pada posisi ke dua atau ke tiga, dimana perusahaanperusahaan ini menyerang pemuka dan pesaing-pesaing lain dengan tawaran yang agresif untuk memperoleh lebih banyak market share menurut Kotler, 2005, p.291.

Menurut Kotler \& Keller, 2007): strategi pemotongan harga, strategi produk murah, strategi produk prestise, strategi pengembangan produk, strategi inovasi produk, strategi penyempurnaan layanan, strategi inovasi distribusi, strategi penekanan biaya produksi dan produksi yang intensif.

"Perusahaan yang berupaya secara gencar merebut pangsa pasar terutama pangsa pasar dari perusahaan pemimpin pasar". Djaslim Saladin (2006:117)

Perusahaan yang menempati kedua, ketiga dan seterusnya dapat disebut sebagai Peringkat kedua. Peringkat kedua yang cukup besar seperti Colgate, Ford, dan Pepsi Cola. Perusahaan peringkat dua ini dapat menyerang si pemimpin pasar secara agresif untuk merebut pangsa pasar di sebut sebagai penantang pasar. Jenis perusahaan yang diserang:

1. Perusahaan pemimpin besar

2. Perusahaan setara/sebanding yang tidak berjalan dengan normal dan kekurangan dana.

3. Perusahaan kecil lokal dan regional yang tidak berjalan dengan baik dan kekurangan dana.

\section{Pengikut pasar (Market Follower)}

Berdasarkan perbedaan karakteristik perusahaan, telah mengklasifikasikannya posisi persaingan menurutu Kotler dan Amstrong (2010) 
Perusahaan yang mengambil sikap tidak mengusik pemimpin pemimpin pasar dan hanya puas dengan cara menyesuaikan diri terhadap kondisi-kondisi pasar.

Karakteristik pengikut pasar terdiri atas:

1. Selalu mencoba menonjolkan ciri khasnya kepada pasar sasaran, seperti lokasi, pelayanan, keunggulan produk, dan sebagainya.

2. Memilih untuk meniru produkatau strategi pemimpin pasar dan penantang pasar daripada menyerang mereka.

3. Biasanya memperoleh laba yang tinggi karena tidakmenanggung beban pengeluaran yang tinggi untuk inovasi.

Pengikut pasar (Market Follower) melakukan kegiatan menurut Kotler \& Keller, 2007) seperti sebagai berikut:

a. Cloner yaitu meniru dan menyamai segmen pada bauran pemasaran pemimpin pasar.

b. Imitiator yaitu membuat beberapa differensiasi nama tetap meniru pemimpin pasar dalam hal pembauran pasar dan bauran pemasaran.

c. Adapter yaitu mencontohproduk-produk pemimpin pasar, memproduksinya namun dengan improvisasi.

Strategi pengikut pasar adalah "strategi perusahaan tidak melakukan serangan, tetapi berusaha mempertahankan pelanggan dengan menonjolkan sifat khasnya" menurut Fandy Tjiptono (2000:319).

Mereka dapat tenang dan tidak menimbulkan gejolak, di sebut pengikut pasar. Contoh penantang pasar, yang mengejar pemimpin pasar, bahkan melampaui:

- Canon sekarang melampaui Xerox.

- Toyota sekarang melampaui General Motors.

- British Airways sekarang melampaui pendahulunya Pan Am

\section{Relung Pasar (Market Niche)}

Berdasarkan perbedaan karakteristik perusahaan, telah mengklasifikasikannya posisi persaingan menurutu Kotler dan Amstrong (2010) Perusahaan yang mengkhususkan diri melayani sebagian pasar yang diabaikan perusahaan besar, dan menghindari bentrok dengan perusahaan besar. Karakteristik market nicher antara lain:

1. Biasanya berspesialisasi secara geografis.

2. Merupakan perusahaan yang dayabeli dan ukurannya cukup besar agar bisa menguntungkan.

3. Memiliki potensi untuk berkembang.

4. Memiliki keterampilan dan sumber daya yang memadai untuk memenuhi kebutuhan ceruk pasar tersebut secara efektif.

5. Mampu mempertahankan diri dari pesaing besar dengan 'customer goodwill' yang dibinanya.

"Niche marketing as finding small groups of customer that can be served within a segment" (pemasaran relung sebagai menemukan kelompok kecil pelanggan yang dapat dilayani dalam suatu segmen) menurut Michaelson (1988:20) mengatakan "niche marketing is defined as the process of targeting sub-market segments that are distinguished from largermarkets according to he need for a special combination of benefits" (pemasaran relung didefinisikan sebagai proses penargetan segmensub-market yang berbeda dari pasar 
yang lebih besar sesuai dengan kebutuhan kombinasi manfaat yang khusus) menurut Kotler (1997) dikutip oleh Drea dan Hanna (2000:33).

Dalgic dan Leeuw (1994:40) mendefinisikan pemasaran relung sebagai "a small market consisting of an individual customer or a small group of customers with similar characteristics or needs. In niche marketing, a company focuses on a market niche exhibiting the above characteristics". (pasar kecil yang terdiri dari pelanggan individu atau kelompok pelanggan kecil dengan karakteristik atau kebutuhan yang sama. Dalam pemasaran relung, perusahaan fokus pada relung pasar yang menggambarkan karakteristik-karakteristik di atas.

\section{METODE PENELITIAN}

Metode penulisan artikel ilmiah ini menggunakan studi literatur dan studi kepustakaan. Dengan mengkaji berbagai referensi sesuai dengan teori yang dibahas, khusunya dalam lingkup Manajemen Pemasaran. Disamping itu menganalisis artikel-artikel ilmiah yang bereputasi dan juga artikel ilmiah dari jurnal yang belum bereputasi. Semua artikel ilmiah yang di citasi bersumber dari academia.edu dan Scholar Google.

\section{HASIL DAN PEMBAHASAN}

\section{Pengaruh/hubungan pemimpin pasar (Market Leader) terhadap persaingan pasar}

The real market leader tidak hanya menguasai pangsa pasar lebih besar dari kompetitornya. Jika menguasai $1 \%$ pangsa pasar lebih besar saja, sebuah merk bisa disebut market leader. Namun, ia baru layak menyandang embel-embel 'the real" jika memiliki pangsa pasar yang lebih dari 50\%. Dan biasanya, jika sebuah merk sudah mendominasi lebih dari setengah pangsa pasar, maka posisi kompetitor-kompetitor pun pasti jauh di bawahnya. Karena sisanya diperebut-kan oleh sejumlah pemain. Umumnya merk/produk yang sukses di pasar dan menjadi market leader adalah merk yang inovatif dari sisi produk, proses produksi dan marketingnya. Inovasi pada produk yang terus menerus sangat penting supaya produk tetap bertahan posisinya dalam persaingan yang ketat. Sedangkan inovasi pada proses produksi ditujukan untuk terus memperbaiki kualitas produk dan efisiensi biaya produksi. Dan inovasi pada sisi pemasaran atau marketing dimaksudkan untuk memenangkan strategi kompetisi merk, baik melalui analisis pelanggan, kompetitor dan kompetensi supply. Tetapi tidak selalu produk yang superior dan pemegang market leader adalah produk yang pertama kali launching. Bisa jadi sebuah produk menjadi superior kalau ia adalah produk pengikut atau follower alias me too. Contohnya merk So Klin.

Parameter superioritas suatu produk/ merk, tidak dapat dilihat dari apakah produk itu market leader atau tidak di pasar, tetapi juga harus dilihat dari omsetnya, share of voicenya (hal ini bias dilihat dari biaya iklannya), langkah terobosan pemasarannya, tingkat awareness-nya, pertumbuhan-nya stabil atau tidak dan besar kecilya profit yang masuk ke kas perusahaan.

Shimaguchi (2006) mengemukakan Matriks Posisi Bersaing (Competitive Position Matrix) sebagai berikut: 


Tabel 1 : Matriks Posisi Bersaing
\begin{tabular}{|l|c|c|c|}
\hline $\begin{array}{l}\text { Relative Position } \\
\text { of Managerial }\end{array}$ & \multicolumn{2}{|c|}{ Quantity } \\
\cline { 3 - 4 } $\begin{array}{l}\text { Resources } \\
\text { Quality }\end{array}$ & Large & Small \\
\cline { 2 - 4 } & Low & Leader & Nicher \\
\hline
\end{tabular}

Sumber : Shimaguchi, 2006

Quantitative managerial resources terdiri dari jumlah penjualan, kekuatan modal, kapasitas produksi, dan sebagainya. Sedangkan qualitative managerial resources terdiri dari kekuatan merek, pemasaran, teknologi, kepemimpinan, dan lain-lain. Hasil dari mapping inilah yang digunakan sebagai dasar penentuan strategi bersaing bagi masing-masing perusahaan.

Untuk tetap bertahan sebagai yang nomor satu atau sebagai pemimpin pasar, perusahaan dituntut untuk melakukan tindakan di tiga bidang. Pertama, perusahaan harus menemukan cara untuk memperbesar permintaan pasar keseluruhan. Kedua, perusahaan harus melindungi pangsa pasarnya sekarang melalui tindakan defensif dan ofensif yang tepat. Ketiga, perusahaan harus berusaha meningkatkan pangsa pasarnya lebih jauh, bahkan jika ukuran pasarnya tetap sama.

Kegiatan yang akan dilakukan mempunyai tujuan untuk memberikan pemahaman kepada siswa melalui penyuluhan tentang strategi menciptakan market leader untuk menghadapi persaingan pasar. Kegiatan ini diharapkan dapat memberikan dampak positif bagi peserta kegiatan. Kemudian memberikan pemahaman kepada siswa bahwa dengan adanya penyuluhan tersebut usaha-usaha kecil menengah diharapkan dapat membantu dalam meringankan berbagai permasalahan-permasalahan yang muncul salah satu menghadapi persaingan pasar.

\section{Pengaruh/hubungan Penantang Pasar (Market Challenger) terhadap kompetisi/persaingan pasar}

Menurut Kotler dan Armstrong (2000:577): "A runner up firm that is fighting hard to increase its market share in an industry". Penantang pasar adalah perusahaan di belakang pemimpin pasar yang berusaha keras untuk meningkatkan pangsa pasarnya dalam suatu industri. Menurut Kotler(2004, p.580) dalam mendefinisikan tujuan strategi dan pesaing, yang perlu diperhatikan oleh market challenger adalah: "A market challenger must first define which competitors to challenge and its strategic objective. The challenger can attack the market leader. This is a high-risk but potentially high-gain strategy that makes good sense if the leader is not serving he market well. To succeed with such an attack, a company must haves ome sustainable competitive advantage over the leader. This might be a cost advantage leading to lower prices or the ability to provide better value at a premium price." Artinya, penantang pasar harus melakukan langkah awal untuk mendefinisikan sasaran strategisnya. Prinsip militer mengenai sasaran menyatakan bahwa setiap tindakan militer kedepan harus jelas didefinisikan, ditentukan, dan dimampukan untuk mencapai tujuan. Tujuan strategis dari kebanyakan penantang pasar adalah untuk meningkatkan pangsa pasar, memikirkan bahwa hal ini akan menjadi keputusan yang lebih menguntungkan, daripada menghancurkan pesaing atau mengurangi pangsanya, dan memikirkan pertanyaan siapa pesaingnya. Jadi prioritas utama adalah menguasai pangsa pasar bukan pesaing. Ada dua hal pokok yang perlu direncanakan dengan baik oleh market challenger, yaitu menentukan lawan dan sasaran strategi serta memilih strategi penyerangannya. Hal pertama adalah menentukan lawan dan strategi. Prinsip 
militer mengharuskan setiap operasi diarahkan pada sasaran yang jelas, dapat dicapai dan bersifat menentukan.

Perusahaan yang menempati urutan kedua, ketiga dan seterusnya dapat disebut peringkat berikutnya (runner up) atau pengikut. Beberapa, seperti Colgate, Ford, Montgomery Ward, Avis, Westinghouse dan Pepsi-Cola, cukup besar. Perusahaan peringkat berikutnya ini dapat mengambil salah satu dari dua sikap. Mereka dapat menyerang pemimpin secara agresif untuk mendapatkan pangsa pasar (penantang pasar \pm market challenger). Atau mereka mengikuti permainan dan tidak menimbulkan gejolak (pengikut pasar \pm market follower). Ada banyak kasus penantang pasar mengejar pemimpin pasar atau bahkan melampaui pemimpin. Canon, yang hanya sepersepuluh ukuran Xerox di pertengahan 70an, sekarang memproduksi lebih banyak mesin fotokopi daripada Xerox, Toyota sekarang memproduksi lebih banyak mobil daripada General Motors, Nikon lebih banyak memproduksi kamera bagus daripada Leica, dan British Airways menerbangkan lebih banyak penumpang internasional daripada pemimpin terdahulu, Pan Am. Para penantang ini berambisi besar dan menggunakan sumber daya mereka yang lebih kecil dengan lebih baik, sementara pemimpin pasar menjalankan bisnis mereka seperti biasa Strategi Penyerangan yang bisa digunakan oleh penantang pasar, yaitu:

1. Menetapkan Sasaran Strategis dan Lawan

Langkah awal yang harus dilakukan oleh penantang pasar adalah menetapkan sasaran strategis, jadi harus diarahkan pada sasaran yang jelas, menentukan, dan bisa dicapai. Sasaran strategisnya adalah peningkatan bagian pasar, dengan harapan bahwa hal itu akan menghasilkan profitabilitas yang lebih tinggi. Pada dasarnya penyerang dapat memilih untuk menyerang salah satu dari tiga jenis perusahaan: a. Perusahaan menyerang pemimpin pasar.

a. Strategi ini berisiko tinggi namun memberikan imbalan yang tinggi dan masuk akal bila pemimpin pasar adalah pemimpin palsu yang tidak melayani pasar dengan baik. Bidang yang harus diteliti adalah kebutuhan konsumen dan ketidakpuasan konsumen.

b. Perusahaan menyerang perusahaan-perusahaan yang besarnya sama, yang kurang berhasil, dan yang kekurangan dana.

Dalam strategi ini, penantang pasar dapat menyerang perusahaan yang memiliki produk tua, yang mengenakan harga berlebihan, atau yang tidak memuaskan pelanggan. Kepuasan konsumen maupun potensi pembaruan perlu diteliti dengan mendalam.

c. Perusahaan menyerang perusahaan-perusahaan regional yang lebih kecil, yang kurang berhasil, dan yang kekurangan dana.

Beberapa perusahaan besar tumbuh menjadi kuat tidak hanya merebut konsumen dari pesaing, tetapi juga dengan melahap perusahaan-perusahaan kecil lainnya.

2. Memilih Strategi Penyerangan

Daya tempur yang terbaik harus dipusatkan pada tempat dan waktu yang tepat, untuk fungsi yang menentukan. Jika ada lawan yang menduduki daerah pemasaran tertentu, maka ada lima strategi yang dapat dilakukan, yaitu:

a. Serangan Frontal

Penyerang mengerahkan kekuatannya tepat berhadapan dengan lawan, penyerang lebih menyrang kekuatan lawan daripada meyerang kelemahan lawan, bagaimana hasilnya tergantung siapa yang memiliki kekuatan dan daya tahan yang lebih 
besar. Biasanya penyerang menandingi produk, iklan, harga, dan lain-lainnya dari lawan.

b. Serangan Sisi/Melambung

Daerah yang diperkirakan akan diserang selalu memiliki pasukan yang terkuat, jadi perusahaan penyerang harus memiliki akal untuk mengetahui kelemahan perusahaan lawan. Ada dua strategi serangan yang dapat diterapkan, yaitu: serangan geografis ditujukan pada daerah-daerah pemasaran yang tidak tertangani dengan baik oleh pesaing. Serangan segmen, menutup segmen pasar yang belum terpenuhi oleh market leader. Jadi dasar dari strategi ini adalah menemukan kebutuhan konsumen dan memenuhinya.

c. Serangan Mengepung

Perusahaan penyerang berusaha menembus daearah pemasaran lawan. Strategi ini dijalankan dengan serangan besar-besaran terhadap berbagai front, sehingga lawan harus melindungi bagian depan, samping, dan belaka pada saat yang bersamaan. Perusahaan penantang dapat memasarkan apa saja yang ditawarkan oleh pesaing, dan melebihi apa yang dimiliki pesaing. Sehingga tawaran perusahaan penantang tidak mungkin ditolak konsumen. Tetapi pihak penyerang harus memiliki sumber daya yang lebih dibanding yang dipunyai lawan.

d. Serangan Lintas

Strategi menyerang secara tidak langsung serta menjauhkan diri dari setiap gerakan yang mengarah kedaerah pemasaran pesaing. Serangan dilakukan dengan cara melintasi pesaing dan menyerang pasar yang lebih lemah, agar basis sumber daya dapat diperluas. Ada tiga pendekatan diversifikasi (pembedaan), yaitu: produk-produk yang tidak berkaitan, pasar geografis yang baru bagi produk yang ada, dan meloncat ke teknologi baru untuk menggantikan produk yang ada saat ini.

e. Serangan Gerilya

Khusus bagi perusahaan-perusahaan kecil, terutama yang kekurangan modal untukmenyerang pasar. Serangan ini dilancarkan dengan serangan-serangan kecil dan terputus-putus pada berbagai wilayah lawan. Perusahaan juga dapat menyerang secara beruntun dengan promosi yang pendek dan potongan harga pada beberapa tempat secara sembarang dalam wilayah pasar yang dikuasai perusahaan yang lebih besar. Tindakan ini diperhitungkan untuk secara perlahanlahan melemahkan kekuasaan lawan atas pasar, dimana tujuannya adalah untuk mengganggu dan mengacau lawan dan akhirnya memperoleh tempat berpijak tang tepat.

3. Pengaruh/hubungan pengikut pasar (Market Follower) terhadap kompetisi/ persaingan pasar

Strategi bersaing bergantung pada besar dan posisi masing-masing perusahaan dalam pasar. Perusahaan besar mampu menerapkan strategi tertentu yang tidak bisa dilakukan oleh perusahaan kecil. Tetapi hanya dengan skala besar saja tidaklah cukup, karena ada beberapa strategi bagi perusahaan besar yang mampu menjamin keberhasilannya, akan tetapi ada juga strategi yang dapat merugikan dirinya sendiri. Dan bukanlah merupakan sesuatu hal yang jarang terjadi bahwa perusahaan kecil dengan strateginya sendiri mampu rnenghasilkan tingkat keuntungan yang sama atau 
bahkan lebih baik daripada yang diperoleh perusahaan besar. Strategi umum yang biasa dilakukan oleh market follower yaitu:

1. Mengikuti dari dekat. Market follower berusaha menyamai perusahaan pemimpin pasar pada sebanyak mungkin segmen pasar dan wilayah bauran pemasaran.

2. Mengikuti dari jauh. Dalam strategi ini market follower membuat beberapa differensiasi, namun tetap mengikuti market leader dalam hal pembauran pasar.

3. Mengikuti secara selektif. Market follower mengikuti dengan dekat beberapa hal yang dilakukan market leader, namun pada hal-hal yang lain perusahaan berjalan dengan sendiri.

Sikap Konsumen terhadap Merek Pionir dan Merek Pengikut Penelitian-penelitian tentang merek pionir dan merek pengikut telah menuju pada sebuah kesimpulan umum bahwa konsumen mempunyai sikap menyukai merek pionir. Penelitian Albert dan Kamins (1995) dan Niedrich dan Swain (2003) turut memperkuat kesimpulan tersebut. Sikap terhadap merek pionir dan merek pengikut dibentuk oleh persepsi-persepsi konsumen terhadap atribut-atribut merek yang dihasilkan oleh beliefs konsumen tentang merek pionir dan merek pengikut. Jadi persepsi konsumen terhadap atribut-atribut merek pionir dan merek pengikut akan membentuk sikap konsumen terhadap merek pionir dan merek pengikut

\section{Offensive and Defensive Competitive Strategy}

Dari analisa posisi, diketahui posisi PT X adalah follower, sehingga strategi yang dapat digunakan untuk memperbesar pasar adalah:

1. Memperbesar permintaan pasar total. Hal ini dapat dilakukan dengan:

a. Meningkatkan kinerja sales untuk mendapatkan pelanggan baru dan meningkatkan penetrasi pasar dengan produk yang ada.

b. Melindungi penggunaan produkTim sales harus lebih proactive untuk mencari tahu kebutuhan pasar, memprediksi kebutuhan, dan menawarkan solusi ke konsumen.

c. Market-Follower Strategy Memanfaatkan tim R\&D untuk selalu mencari produk sejenis yang lebih baik.

2. Attack Strategy PT X harus berusaha menyerang untuk memperbesar pangsa pasar.

\section{Pengaruh/hubungan nicher terhadap kompetisi/persaingan pasar}

Pasar konsumen merupakan pasar dengan segmen yang sangat beragam, apakah berdasarkan demografi, geografi, psikografi, atau yang lainnya. Perusahaan-perusahaan telah menyediakan berbagai produk untuk memenuhi kebutuhan konsumen hampir di segala jenis segmen. Persaingan di pasar konsumen yang melibatkan perusahaan besar dan juga kecil berlangsung sangat sengit dan pada umumnya perusahaan-perusahaan besar memperoleh posisi persaingan yang lebih baik karena memiliki sumber daya relatif lebih unggul daripada perusahaan kecil.

Definisi pemasaran relung dikemukakan oleh Michaelson (1988:20)" niche marketing as finding small groups of customer that can be served within a segment" (pemasaran relung sebagai menemukan kelompok kecil pelanggan yang dapat dilayani dalam suatu segmen). Kotler (1997) dikutip oleh Drea dan Hanna (2000:33) mengatakan "niche marketing is defined as the process of targeting sub-market 
segments that are distinguished from larger markets according to the need for $a$ special combination of benefits" (pemasaran relung didefinisikan sebagai proses penargetan segmen submarket yang berbeda dari pasar yang lebih besar sesuai dengan kebutuhan kombinasi manfaat yang khusus).

Dalgic dan Leeuw (1994:40) mendefinisikan pemasaran relung sebagai " a small market consisting of an individual customer or a small group of customers with similar characteristics or needs. In niche marketing, a company focuses on a market niche exhibiting the above characteristics". (pasar kecil yang terdiri dari pelanggan individu atau kelompok pelanggan kecil dengan karakteristik atau kebutuhan yang sama. Dalam pemasaran relung, perusahaan fokus pada relung pasar yang menggambarkan karakteristik-karakteristik di atas.

Peluang pasar yang berpotensi dengan permintaan daun ketumbar dalam kuantitasyang lebih tinggi dan harga yang lebih tinggiberasal dari usaha catering dan restoran hotelberbintang dengan sasaran konsumen akhirwarga negara asing, belum dijadikan targetpasar oleh para petani. Menurut Kotler (2003) market nichemerupakan pasar yang memilikikarakteristik tidak menarik bagi pesaing dan memiliki pertumbuhan yang potensial untuk dipasarkannya sebuah produk yang memenuhi kebutuhan konsumen yang berbeda dan mampu untuk membayar dengan harga premium akan membawa keuntungan bagi produsen yang dapat menspesialisasikan produknya. Membangun relung pasar (market niche) memberikan kesempatan pelaku usaha untukmenjual produk dan jasa kepada kelompok yangtidak ditujukan oleh pelaku usaha lainnya. Tantangan saat ini dan lingkungan usaha yangcepat mengalami perubahan menuntut sebuah inovasi untuk dapat mengembangkan suatu bisnis. Inovasi ini hanya dapat dicapai melaluispesialisasi, diferensiasi dan pemanfaatan peluang pasar baru seperti dalam relung pasar yangmemiliki ukuran, laba dan potensi pertumbuhan (Abrar et al., 2009). Menurut Little et al (2010), kreativitas yang ditawarkan saluran pemasaran market niche muncul dari pemindahan konsumen produk pertanian organik dari pasar konvensional ke relung pasar.

Menurut Kotler (2003) dalam Parrish (2006) mengatakan bahwa niche markets memiliki karakteristik sebagai berikut:

a. Konsumen memiliki kebutuhan yang berbeda

b. Konsumen akan membayar harga premium untuk memenuhi kebutuhan mereka kepada perusahaan yang terbaik

c. Niche market tidak menarik bagi pesaing

d. Perusahaan mendapatkan keuntungan tertentu melalui spesialisasi

e. Niche market memiliki ukuran, profit, dan pertumbuhan potensial

Alasan untuk mengimplementasikan niche market strategy yang paling utama adalah demi sebuah keuntungan atau profit. Perusahaan yang menerapkan niche market strategy mengetahui kelompok pelanggan sasaran dengan begitu baik sehingga market nicher dapat memenuhi kebutuhan mereka secara lebih baik daripada perusahaan besar lain yang biasa menjual ke niche market tersebut. Akibatnya, market nicher dapat mengenakan markup biaya karena adanya nilai tambah. Sementara pemasar massal mencapai volume tinggi, market nicher mencapai margin yang tinggi (Kotler, Philip; Armstrong, Gary, 2008).

Jain dalam Dalgic dan Leeuw (1994) memandang niche market strategy sebagai strategi pemasaran tunggal yang dapat digunakan untuk alasan berikut:

1. Menghindari konfrontasi persaingan dengan pesaing yang lebih besar dan mencurahkan energinya untuk melayani pasar yang unik 
2. Untuk meningkatkan kesempatan

3. Untuk kelangsungan perusahaan

\section{Pengaruh/hubungan pemimpin pasar (Market Leader) terhadap pertumbuhan pasar/Pengembangan Pasar}

Beberapa penelitian yang terkait dengan penelitian ini antara lain oleh Leifer (2000) bahwa inovasi pada dasarnya bukan hanya terkait dengan pengembangan produk dan jasa, namun selain itu terkait pula pengembangan kompetensi perusahaan dimana di dalamnya terdapat SDM perusahaan.

Menurut Gunday, 2011, inovasi produk sebagai tingkat kebaruan suatu produk dengan ditunjukkan dengan perkenalan produk baru yang secara signifikan meningkatkan karakteristik ataupun penggunaannya. Inovasi yang berkelanjutan pada akhirnya akan menciptakan keunggulan kompetitif dan Menurut Stata (1992:2) agar dapat bersaing di pasar yang dinamis, perusahaan harus selalu terlibat dalam inovasi yang berkelanjutan.

Kemampuan perusahaan dalam berinovasi ini akan meningkatkan perusahaan dalam menghasilkan produk-produk dan layanan bisnis yang berdaya saing tinggi. Menurut Morgan, 2012 dan Barny, 1991, bahwa keunggulan daya tarik produk adalah tambahan nilai yang diberikan produk yang sulit ditiru, langka, bernilai dan tidak tergantikan yang membedakan dengan produk pesaingnya.

Kotler and Armstrong [10] mengemukakan bahwa dalam usaha memperluas atau mempertahankan pangsa pasar, leader dapat menerapkan enam strategi bersaing yaitu position defense, flanking defense, preemptive defense/strategy, counteroffensive defense, mobile defense dan contraction defense, sedangkan challenger dapat menerapkan lima strategi bersaing yaitu frontal attack, flanking attack, encirclement attack, bypass attack dan guerilla attack. Strategi bersaing yang diterapkan oleh leader dan challenger tersebut jika dikaitkan dengan tiga strategi dasar ekspansi kapasitas maka terdapat tiga strategi bersaing melalui strategi ekspansi kapasitas yang secara rasional digunakan oleh leader yaitu preemptive strategy (PS), position defense (PD) dan counteroffensive defense (COD) dan dua strategi bersaing oleh challenger yaitu encirclement attack (EA) dan frontal attack (FA).

Kondisi pasar tersebut menyebabkan semakin tinggi dan ketatnya persaingan antar pemasar dalam merebut pangsa pasar yang pertumbuhannya lambat atau stagnan. Untuk dapat bertahan dan merebut "kue pasar" yang ada, para pemasar berlomba-lomba melakukan aktivitas-aktivitas pemasaran yang positif dan inovatif seperti menawarkan berbagai kemudahan bagi konsumen dalam pembelian barang konsumsi, pemberian berbagai macam fasilitas, penawaran produk-produk baru,dsb. Disamping itu ketatnya persaingan juga menimbulkan kondisi persaingan yang bersifat negatif seperti adanya perang harga, penipuan kepada konsumen, dsb.

Produk-produk perusahaan dengan merek yang sudah "mapan" (establish brand) juga mengalami kondisi persaingan yang sama beratnya dengan produk-produk bermerek baru ataupun merek yang kurang populer. Sehingga merek yang sudah mapan harus berjuang agar tidak kalah dengan merek-merek yang baru. (Kumar,2005)

Ada banyak strategi yang dapat digunakan untuk bertahan dan menang dalam persaingan. Salah satu strategi jitu yang dapat digunakan oleh pemasar adalah dengan menggunakan 
strategi manajemen merek seperti strategi co-branding, brand extention, brand acquisition, brand repositioning dan masih banyak strategi manajemen merek lainnya.

\section{Pengaruh/hubungan Penantang Pasar (Market Challenger) terhadap pertumbuhan pasar}

Perusahaan disebut dengan penantang pasar bila dengan agresif mencoba memperluas pangsa pasarnya dengan jalan menantang pemimpin pasar, pesaing-pesaing sebayanya atau perusahaan yang lebih kecil dalam industri sejenis (Kottler, 1997).

Satu langkah awal yang harus dilakukan penantang pasar adalah menetapkan sasaran strategis. Sasaran strategis dari kebanyakan penantang pasar ialah peningkatan bagian pasar. Mereka menuju sasaran tersebut dengan harapan bahwa hal itu akan menghasilkan profitabilitas yang lebih tinggi. Pada dasarnya penyerang dapat memilih menyerang salah satu dari tiga jenis perusahaan (Kottler, 1997):

1. Perusahaan penyerang pemimpin pasarpilihan ini membawa resiko tinggi, tetapi bisa merupakan strategi yang akan bamyak menghasilkan dan memang benar-benar masuk akal bila sipemimpin pasar bukanlah "pemimpin yang sejati", dan ternyata tidak memenuhi kebutuhan pasar dengan sempurna. Bidang yang harus diteliti dengan cermat adalah kebutuhan konsumen atau ketidakpuasan mereka.

2. Perusahaan menyerang perusahaan-perusahaan yang besarnya sama, yang kurang berhasil serta kekurangan dana.

3. Perusahaan menyerang perusahaan - perusahaan regionalyang lebih kecil yang kurang berhasil serta kekurangan dana.

Strategi pemotongan harga. Satu strategi menyerang yang utama bagi penantang pasar adalah memasarkan produk yang bisa dibandingkan dengan produk milik pemimpin pasar, namun dengan harga yang lebih murah. Agar strategi pemotongan harga ini bisa berhasil, tiga syarat harus dipenuhi yaitu Pertama, challenger harus meyakinkan pembeli bahwa produk dan jasanya memang bisa diabandingkan dengan milik market leader. Kedua, pembeliharus sensitif terhadapa perbedaan harga dan tidak segan-segan berpindah ke merek lain. Ketiga, market leader harus mempertahankan harga jualnya dan menolak ikut menurunkan harga.

Beberapa strategi serangan yang spesifik bagi penantang pasar (Kotler \& Keller, 2007); Strategi pemotongan harga, strategi produk murah, strategi produk prestise, strategi pengembangbiakan produk, strategi inovasi produk, strategi penyempurnaan layanan, strategi inovasi distribusi, strategi penekanan biaya produksi, dan promosi yang intensif

Penantang harus melangkah mclampaui lima stralegi luas ini dan mengembangkan strategi yang lebih spesifik. Semua aspek program pemasaran dapat bertindak sebagai basis serangan, seperti produk berharga murah atau produk diskon, produk dan jasa baru atau yang diperbarui, ragam penawaran yang lebih luas, dan strategi distribusi inovatif. Keberhasilan penantang tergantung pada penggabungan beberapa strategi untuk meningkatkan posisinya seiring berjalannya waktu. "Catalan Pemasaran: Membuat Yang Lebih Kecil Menjadi Lebih Baik" memberikan beberapa tips tambahan bagi merek penantang 


\section{Pengaruh/hubungan pengikut pasar terhadap pertumbuhan pasar}

Banyak perusahaan yang lebih suka menjadi pengikut pemimpin pasar daripada menantang pemimpin pasar. Pola "hidup berdampingan merupakan hal umum dalam industri padat modal dan memiliki produk yang homogen seperti baja, pupuk, dan kimia.

Peluang diferensiasi produk dan diferensiasi citra sangat kecil; mutu pelayanan sebanding, dan sensitivitas harga tinggi serta perang harga dapat terjadi setiap saat. Mereka menjadi sadar bahwa menantang perang pasar untuk meraih pangsa pasar dalam jangka pendek, akan mengundang serangan balik. Kebanyakan perusahaan tidak mau mencuri pelanggan perusahaan lain, mereka cenderung memberikan tawaran yang serupa kepada pembeli, mengikuti pemimpin sehingga pangsa pasar menunjukkan stabilitas yang tinggi.

Sebagai pengikut pasar harus mengetahui bagaimana cara memertahankan pelangngan yang ada dan menarik pelanggan baru. Pengikut perlu menonjolkan keunggulan tersendiri ke pasar sasarannya-lokasi, pelayanan yang baik, dan pembiayaan yang rendah.

Pengikut pasar sering merupakan sasaran serangan dari penantang pasar, pengikut pasar harus memertahankan biaya produksi yang rendah, mutu produk serta pelayanan yang tinggi, berusaha memasuki pasar baru ketika suatu pasar terbuka, menentukan arah pertumbuhan, yang tidak mengundang serangan balik.

Perusahaan yang mengambil sikap tidak mengusik pemimpin pasar dan hanya puas dengan cara menyesuaikan diri terhadap kondisis - kondisi pasar.

Karakteristiknya:

a. Selalu mencoba menonjolkan ciri khasnya kepada pasar sasaran seperti lokasi, pelayanan, keunggulan produk dan sebagainya.

b. Memilih untuk meniru produk atau strategi pemimpin atau penantang pasar daripada menyerang mereka.

c. Laba tinggi karena tidak ada beban tinggi untuk inovasi. contoh: Produk minuman serbuk cola - cola meniru produk minuman coca - cola.

\section{Strategi Market Follower}

Dilakukan untuk dapat mempertahankan konsumen dan memperoleh para pelanggan strategi pertumbuhan untuk upaya supaya tidak mendapatkan balasan dari pihak lawan.

Melihat sederet keunggulan yang ditenteng merek pionir, tertutupkah kesempatan bagi para later entrants (follower) untuk memenangkan persaingan? Jawabannya, tidak! Betul kata Schnaars, yang pertama bisa jadi terakhir dan sebaliknya.

Alasannya, follower juga menawarkan banyak kelebihan. Pertama, mereka bisa menghindari produk-produk yang tidak potensial. Kedua, apabila produk itu punya risiko, risikonya sudah ditanggung oleh pionir. Ketiga, biaya R\&D-nya lebih kecil karena follower masuk belakangan di saat pasar itu sudah terbentuk.

Keempat, mereka punya peluang untuk mendapatkan pangsa pasar dari market leader kalau pasarnya lemah. Kelima, biaya untuk mengedukasi konsumen sangat rendah. 
Sebab, proses edukasi sebelumnya sudah dilakukan oleh market leader. Dengan demikian, dapat disimpulkan bahwa brand follower sebetulnya juga mengusung banyak keunggulan.

\section{Pengaruh/hubungan nicher terhadap pertumbuhan pasar}

\section{Strategi Market Nicher}

- Gagasan pokok adalah spesialisasi

- Perusahaan memiliki keahlian dalam hal pasar, konsumen produk dsb.

Pengkhususan yang dapat dipilih :

- Spesialis pemakai akhir,

- Bank khusus untuk melayani satu golongan: bank pensiunan.

- Spesialis tingkat vertikal,

- Khusus dalam saluran distribusi - produksi: Unit Industri Bobin PTPN X,

- Spesialis ukuran pelanggan,

- Melayani konsumen yang diabaikan oleh perusahaan: Distro pakaian big size untuk baju ukuran besar di Bandung.

Spesialis Pelanggan tertentu

Penjualan output pada satu perusahaan saja, Sehingga terdapat spesialisasi pada pangsa pasar yang akan dilirik, berikut beberapa macam spesialisasi tersebut:

1. Spesialis geografis

Melayani satu wilayah khusus saja: Radar Jember

2. Spesialis produk atau lini produk Spesifik pada satu bagian dari produk: industri laboratorium, ada perusahaan yang hanya memproduksi lensa mikroskop saja.

3. Spesialis sifat atau karakter produk

Produksi pada satu jenis produk saja: perusahaan transportasi PJKA

4. Spesialis pesanan

Produksi berdasarkan orderan pelanggan: perusahaan industri kerajinan

5. Spesialis kualitas atau harga

Hanya berorientasi pada satu segmen golongan konsumen saja: butik

6. Spesialis jasa.

Menyediakan jasa yang lain daripada yang lain: pegadaian, rumah persemayaman.

7. Spesialis saluran distribusi

Khusus pada satu saluran distribusi saja

Sekarang saatnya untuk mengindentifikasi dan menemukan ceruk pasar untuk bisnis kamu, ikuti empat langkah berikut:

1. Keunggulan dan Daya Tarik Produk

Mulai dengan mempertimbangkan apa yang akan ditawarkan dan apa yang yang menjadi kelebihan produk tersebut. Strategi pemasaran ini sangat berperan dalam kekuatan dan perspektif unik sebuah produk. Jadi, renungkan inovasi dan keunikan dari brand yang akan di promosikan. Hal ini berkaitan dengan;

a. Masalah spesifik apa yang diselesaikan dengan produk tersebut?

b. Masalah apa yang bisa selesaikan lebih baik oleh pesaing? 
c. Siapa saja yang akan terbantu oleh produk tersebut?

2. Lakukan riset industri

Setelah memiliki gagasan tentang sebuah inovasi yang bisa ditawarkan oleh produk dari brand yang akan di promosikan. Validasikan bahwa itu adalah ide yang masuk akal. Lakukan analisis kompetitif untuk melihat apakah ada pesaing di ruang ini dan jika ada, apa yang sudah dilakukan merek-merek tersebut.

\section{Kenali Calon Konsumen}

Cara lain untuk mendapatkan wawasan dan memicu inspirasi adalah melihat dari dekat target konsumen dan mengidentifikasi apa yang mereka inginkan dan butuhkan di saat ini atau masa depan. Mengenal calon konsumen dapat membantu mengembangkan sebuah produk atau cara menyampaikan pesan pada media promosi yang baik kepada mereka.

Untuk ini dibutuhkan riset dengan menggunakan berbagai metode seperti metode focus group discussion (FGD) dengan bekerjasama dengan agen riset konsumen. Selain itu kita juga dapat menggunakan bantuan social media listening tool seperti Socialbakers. Dengan mencari informasi tersebut perusahaan dapat mengidentifikasi kebutuhan konsumen dan menemukan peluang.

4. Pilih Target Segmen dan Selalu Evaluasi

Seperti kebanyakan strategi pemasaran, pengembangan tidak bisa berhenti disaat berhasil membuat strategi pemasaran "niche market" dan menganggapnya akan mencapai hasil yang diinginkan. Perusahaan harus terus menguji ide tersebut, meninjau hasilnya, dan terus menyesuaikannya.

\section{Keuntungan Strategi Bisnis Ceruk Pasar}

Strategi bisnis ceruk pasar fokus pada kelompok masyarakat yang spesifik dan biasanya belum memiliki pesaing. Hal ini akan mempermudah proses branding karena tidak terlalu banyak pesaing yang akan mempengaruhi alam bawah sadar konsumen. Konsumen juga akan lebih percaya dan berani membayar lebih karena produk atau jasa yang anda tawarkan dianggap yang terbaik.

Dalam hampir setiap industri, selalau terdapat perusahaan-perusahaan kecil yang mengkhususkan diri pada sebagian dari pasar dan menghindari bentrok dengan perusahaanperusahaan besar. Prusahaan-perusahaan kecil ini menempati "relung-relung" pasar yang mereka layani dengan efektif melalui spesialisasi dan yang cenderung diabaikan perusahaan-perusahaan besar. Strategi yang ditempuh oleh perusahaan ini disebut penggarap relung pasar (market nicher). Menempati sebagian kecil dari keseluruhan pasar ini tidak hanya diminati oleh perusahaan-perusahaan yang lebih besar dan yang belum mampu di industri tertentu. Perusahaan-perusahaan jenis ini mencoba masuk ke satu atau lebih celah-celah pasar yang aman dan menguntungkan.

Strategi pemasaran yang berhasil sangat ditentukan oleh tigkat kepuasaan yang diperoleh konsumen dari kegiatan pemasaran yang dilakukan perusahaan untuk produknya. Atas dasar ini maka dapatlah dikatakan bahwa tujuan dan sasaran pemasaran suatu produk adalah untuk kepuasaan kepada konsumen.

Setiap perusahaan yang bersaing dalam suatu industri mempunyai strategi bersaing. Usaha mengenali dan mempelajari pesaing merupakan masalah utama yang perlu diselesaikan 
untuk melakukan perencanaan yang efektif. Perusahaan seharusnya membandingkan terusmenerus produk, harga, saluran distribusi, dan promosi mereka dengan yang dilakukan oleh para pesaing dekatnya. Dengan cara ini, perusahaan dapat secara jelas melihat bidangbidang keunggulan dan kelemahan pesaing potensial. Perusahaan dapat melancarkan serangan yang lebih mengena terhadap pesaingnya selain itu juga menyiapkan langkah pertahanan yang lebih kuat terhadap serangan lawan.

\section{Pengaruh/hubungan persaingan terhadap pertumbuhan pasar}

Ada beberapa cara untuk menganalisa laju pesaing dalam dunia bisnis. Anda sebagai pengusaha perlu untuk mengetahui beberapa hal berikut untuk bisa menganalisa laju perkembangan bisnis pesaing;

- Kelengkapan mutu, desain serta bentuk produk pesaing

- Harga yang ditawarkan pesaing

- Lokasi cabang atau saluran distribusi yang dimiliki oleh pesaing

- Promosi yang dijalankan oleh pesaing

- Bagaimana pencana kegiatan kompetitor ke depan

Tipe Persaingan atau Kompetisi dalam Bisnis

1. Persaingan Generik

Tipe persaingan yang pertama adalah persaingan generik. Persaingan generik lebih berfokus pada target pasar atau target market. Tipe ini muncul dikarenakan target pasar maupun konsumen yang sama. Maksudnya, dua perusahaan yang menjual produk dengan konsumen yang sama akan menimbulkan persaingan generik.

2. Persaingan Bentuk

Persaingan bentuk terjadi ketika suatu perusahaan memproduksi barang yang ternyata memiliki kemiripan dengan barang yang diproduksi perusahaan lain. Hal ini mengakibatkan terjadinya persaingan bentuk yang semakin lama akan semakin kompetitif seiring dengan berbagai terobosan yang dilakukan oleh kedua perusahaan tersebut. Contoh dari persaingan bentuk adalah persaingan antara perusahaan yang sama-sama menjual susu.

3. Persaingan Industri

Tipe persaingan yang ketiga dinamakan persaingan industri. Persaingan ini terjadi pada saat perusahaan memproduksi produk yang memiliki kelas produk sama. Salah satu contohnya adalah persaingan yang terjadi antara perusahaan minuman dalam kemasan. Antar perusahaan tersebut sama-sama bersaing untuk menjajakan produk minuman kemasannya sehingga di sini akan terjadi persaingan atau kompetisi.

4. Persaingan Merk

'Untuk jenis persaingan yang satu ini mungkin seringkali Anda menemukannya. Persaingan merk terjadi ketika antar perusahaan memproduksi barang yang sama, namun memiliki perbedaan pada merknya. Padahal harga dari produk tersebut tidak terlalu memiliki perbedaan yang signifikan. Kedua produk tersebut sama-sama merupakan minuman kemasan yang memiliki harga relatif sama. Yang membedakan adalah merk dari keduanya.

Strategi dalam Bisnis

Setelah Anda mengetahui apa saja yang termasuk ke dalam tipe persaingan atau kompetisi dalam dunia bisnis. Maka berikut ini kami juga akan menjelaskan tentang apa saja strategi 
yang harus Anda implementasikan agar supaya Anda bisa menjadi pemenang dalam persaingan yang ketat tersebut.

\section{Harga yang kompetitif}

Strategi pertama yang harus Anda terapkan adalah pastikan harga dari produk yang dijual mempunyai harga yang kompetitif. Maksudnya, harga yang Anda bandrol untuk produk Anda tersebut tidak memiliki perbedaan yang signifikan dengan harga produk dari pesaing. Ketika harga suatu produk malah melambung tinggi sementara harga dari produk pesaing tetap, maka kemungkinan besar Anda tidak akan bisa memenangkan kompetisi tersebut.

Namun, bagi Anda yang memiliki target pasar dengan kelas yang berbeda mungkin Anda masih bisa menaikkan harganya asalkan produk Anda benar-benar berkualitas dan ditunjang dengan berbagai keunggulan lain yang tidak dimiliki oleh produk pesaing. Sebaliknya, harga yang terlalu murah untuk mengikat minat konsumen juga bukan pilihan yang tepat.

Hal seperti ini malah bisa menjadi boomerang untuk produk Anda sendiri. Konsumen pun kemungkinan akan mulai berspekulasi apakah produk yang Anda jual memiliki kualitas yang bagus atau tidak karena Anda menjualnya dengan harga murah.

2. Berikan pelayanan terbaik

Semua bisnis yang dijalani sudah pasti selalu berkaitan dengan target pasar. Target pasar itulah yang dinamakan manusia. Siapapun manusia di dunia ini tidak akan suka diremehkan atau ditindas. Manusia akan sangat suka ketika mereka dihormati atau dihargai karena akan membuatnya merasa senang dan bangga.

Sekarang, strategi memenangkan persaingan pasar tidak selamanya harus mengedepankan harga. Harga memang merupakan faktor yang penting namun terkadang ada faktor lain yang juga harus dipertimbangkan yakni berkaitan dengan pelayanan kepada konsumen. Pelayanan yang terbaik akan membuat konsumen merasa nyaman dan betah menjajal produk Anda.

Bahkan kemungkinan besar produk yang Anda jual semakin memiliki minat yang tinggi dikarenakan pelayanan terbaik yang Anda berikan. Jika bingung bagaimana cara memberikan pelayanan terbaik, coba Anda amati bagaimana karyawan bank melayani nasabahnya. Anda bisa memperhatikan bagaimana mereka bertutur kata dan menghormati nasabahnya. Dari sini Anda bisa belajar untuk memberikan pelayanan terbaik sehingga bisa Anda terapkan di perusahaan Anda.

3. Memperluas pasar

Strategi untuk menjadi pemenang dalam persaingan yang ketat juga bisa Anda lakukan dengan memperluas pasar. Perlu Anda pahami bahwa memperluas pasar di sini bukan berarti Anda harus banyak-banyak membuka outlet atau cabang di berbagai tempat. Hal ini memang diperlukan untuk semakin memperkenalkan produk Anda semakin banyak dikenal.

Namun memperluas pasar juga bisa Anda lakukan dengan cara menambah produk yang Anda jual. Anda juga harus merencanakan seperti apa target pasar Anda terhadap produk baru yang Anda jual tersebut. Contohnya ketika sekarang produk yang Anda jual hanya menjangkau para remaja saja, maka Anda bisa menjual produk yang memiliki target ibu rumah tangga.

4. Melakukan promosi

Promosi juga menjadi sebuah strategi yang sangat penting untuk tetap bersaing. Melakukan promosi dengan benar dan tepat akan membuat produk Anda semakin 
banyak dikenal. Memang biaya untuk promosi sendiri tidak murah. Akan tetapi, cara ini terbukti efektif untuk memperkenalkan produk Anda agar supaya bisa bersaing dan bahkan menjadi pemenang di antara perusahaan lain yang menjual produk yang sama. Maka dari itu, pilihlah promosi yang tepat, termasuk juga orang yang akan mempromosikan produk tersebut juga harus benar-benar mampu.

Pasar Persaingan Sempurna adalah struktur ekonomi di mana tingkat persaingan antara perusahaan berada pada titik sempurna. Berikut ringkasan karakteristik dari Pasar Persaingan Sempurna:

1. Banyak pembeli dan penjual.

2. Produk yang ditawarkan terkesan homogen.

3. Setiap perusahaan mudah untuk masuk dan keluar pasar.

4. Kedua pihak dalam transaksi memiliki pengetahuan lengkap tentang produk, kuantitas, harga, dan kondisi pasar.

5. Tidak ada biaya transportasi dan periklanan.

6. Bebas dari campur tangan Pemerintah.

7. Harga untuk suatu produk seragam di pasar diputuskan oleh permintaan dan penawaran pelaku pasar. Tidak ada perusahaan yang dapat mempengaruhi harga, itulah sebabnya mengapa perusahaan-perusahaan dalam Pasar Persaingan Sempurna menjadi Price Taker.

8. Setiap perusahaan mendapatkan laba secara normal sehingga tidak ada keuntungan dan kerugian yang berlebihan.

\section{Kerangka Konseptual}

Berdasarkan Kajian teori dan review artikel ilmiah, maka conceptual framework kajian pustaka dalam rangka literature review ini adalah:

1) Pengaruh atau hubungan pemimpin pasar terhadap persaingan pasar berdasarkan hasil riset :( Sukotjo. 2010), (Rusno, 2014) dan (PPKM. 2020)

2) Pengaruh atau hubungan penantang pasar terhadap persaingan pasar berdasarkan hasil riset: (Jurnal Managemen, 2010), (Setia Budhi Wilardjo, 2007) dan (Among Makarti, 2011)

3) Pengaruh atau hubungan pengikut pasar terhadap persaingan pasar berdasarkan hasil riset: (Suhandi, 2017), (Cynthia Yulita Wardayanti, 2006) dan (Sudiman, 2018)

4) Pengaruh atau hubungan nicher terhadap persaingan pasar berdasarkan hasil riset: (James Rianto Situmorang), (Sulistyodewi NW, Agriani H. Sadeli, Hesty N. Utami, 2016) dan (Angelia Cindy Hadiprojo dan E. Kusumadmo).

5) Pengaruh atau hubungan pemimpin pasar terhadap pertumbuhan pasar berdasarkan hasil riset: (Laili Savitri Noor, Derriawan, Soebagyo), (Farham H.M. Saleh, 2005) dan (Michael Adiwijaya, 2007)

6) Pengaruh atau hubungan penantang pasar terhadap pertumbuhan pasar berdasarkan hasil riset: (Rusindiyanto), (Yayuk Sri Rahayu) dan revolutionjher Bisnis.

7) Pengaruh atau hubungan pengikut pasar terhadap pertumbuhan pasar berdasarkan hasil riset: (Lembaga Survei ICONESIA, 2015), (Brand Follower! 23 December 2019) dan (Kerajaan berbagi, 2012)

8) Pengaruh atau hubungan nicher terhadap pertumbuhan pasar berdasarkan hasil riset: (Kerajaan berbagi, 2012), (Gilang Irwan, 2020), dan (tulisanterkini.com)

9) Pengaruh atau hubungan persaingan pasar terhadap pertumbuhan pasar berdasarkan hasil riset: (Martina, 2020) dan (www.jurnal.id) 
Dari rumusan masalah penulisan artikel ini dan kajian studi literature review baik dari buku dan artikel yang relevan, maka di perolah rerangka artikel ini seperti di bawah ini.

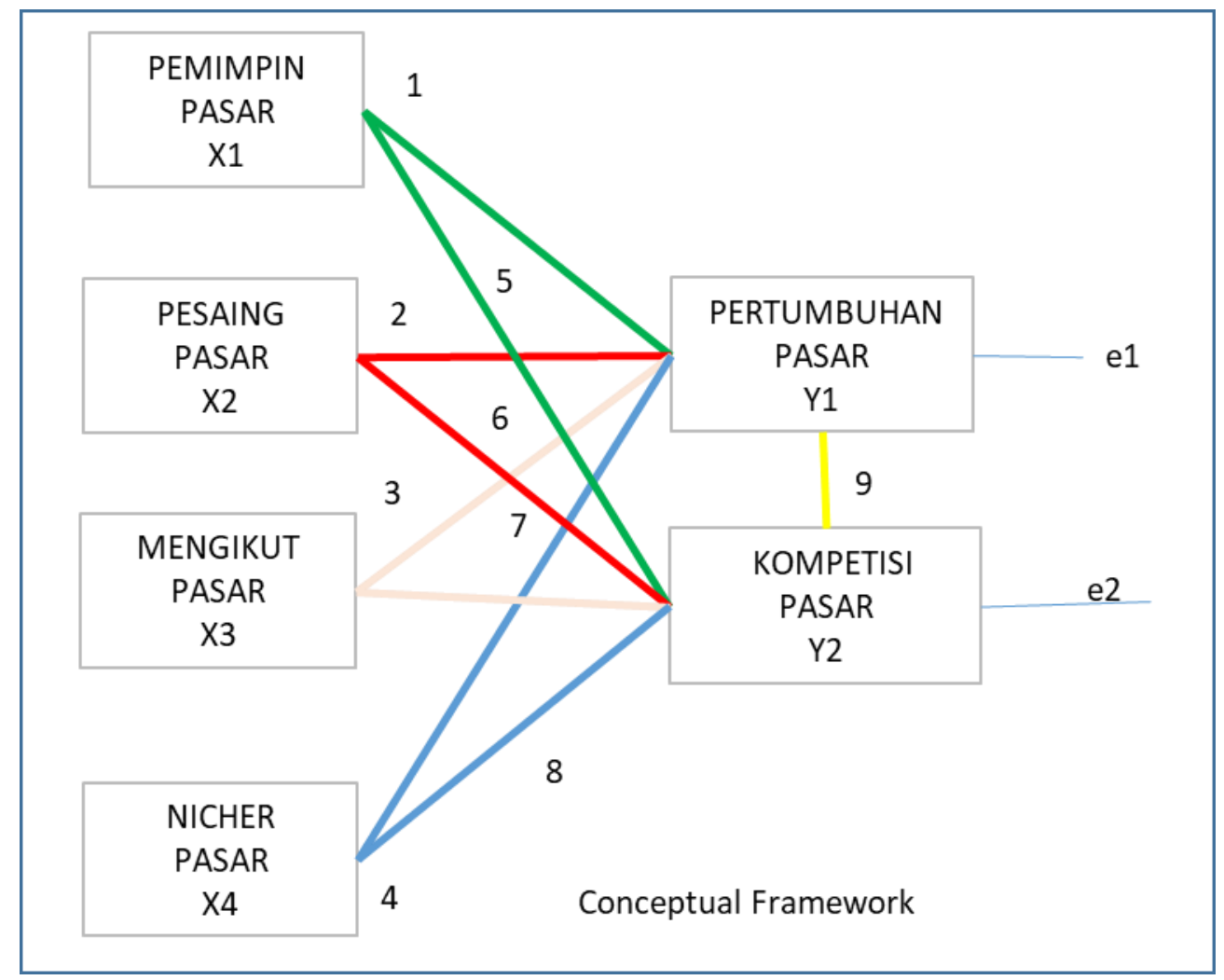

Gambar 1: Conceptual Framework

\section{KESIMPULAN DAN SARAN \\ Kesimpulan}

Berdasarkan rumusan artikel, hasil dan pembahasan yang di kaji dan di bahas pada artikel ini, maka dapat disimpulkan untuk membangun suatu hipoteis guna untuk riset selanjutnya adalah:

1) Pengaruh atau hubungan pemimpin pasar terhadap persaingan pasar

2) Pengaruh atau hubungan penantang pasar terhadap persaingan pasar

3) Pengaruh atau hubungan pengikut pasar terhadap persaingan pasar

4) Pengaruh atau hubungan nicher terhadap persaingan pasar

5) Pengaruh atau hubungan pemimpin pasar terhadap pertumbuhan pasar

6) Pengaruh atau hubungan penantang pasar terhadap pertumbuhan pasar

7) Pengaruh atau hubungan pengikut pasar terhadap pertumbuhan pasar

8) Pengaruh atau hubungan nicher terhadap pertumbuhan pasar

9) pengaruh atau hubungan persaingan pasar terhadap pertumbuhan pasar

\section{Saran}

Bersdasarkan Kesimpulan di atas, maka saran pada artikel ini baik secara akademik atau secara empirik bahwa factor kepemimpinan pasar sangat berpengaruh yang cukup besar terhadap pertumbuhan dan persaingan pasar. Oleh karena itu, bagaimana menciptakan permimpin pasar dari level nicher menjadi pemimpin pasar yang perlu dikembangan lagi melihat kondisi pademi Covid 19. 


\section{DAFTAR PUSTAKA}

Craven David W. and Piercy Nigel F. 2013. Strategic Marketing, 8th edition, McGrawhill

Kotler, Philip and Keller Kevin L. 2016. Marketing Management. 15th Edition Pearson

https://www.pelajaran.co.id/2020/19/pengertian-persaingan-usaha.html

http://e-journal.uajy.ac.id/8694/3/2EM19018.pdf

http://sperkinglove.blogspot.com/2014/10/pengertian-market-leader.html Majalah Ilmiah Ekonomika Volume 13 Nomor 4, Nopember 2010

VALUE ADDED, Vol.3, No.1, September $2006 \pm$ Pebruari 2007 http://jurnal.unimus.ac.id

http://jurnal-sdm.blogspot.com/2010/02/strategi-penantang-pasar-market.html

https://media.neliti.com/media/publications/80188-ID-analisis-posisi-bersaing-

untukmenentuka.pdf

file:///C:/Users/Asus/AppData/Local/Temp/3502-10475-1-PB.pdf

Sukotjo Majalah Ilmiah Ekonomika Volume 13 Nomor 4, Upaya Untuk Menjadi 'The Real Market Leader', Nopember 2010: 130-162

Rusno, Modernisasi, Volume 10, Nomor 3Analisis Posisi Bersaing Untuk Menentukan Strategi Pemasaran Industri Kripik Tempe di Kota Malang oleh, Oktober 2014.

Program Pengabdian Kepada, Masyarakat (PPKM), Universitas Panca Bakti, Vol 1 No 2 (2020): Laporan Pengabdian Kepada Masyarakat Strategi Menciptakan Market Leader Menghadapi Persaingan Pasar.

Strategi Penantang Pasar (Market Challenger) Untuk Meningkatkan Market Share, Jurnal Manajemen, Bahan Kuliah Manajemen, http://jurnal$\underline{\text { sdm.blogspot.com/2010/02/strategipenantang-pasar-market.html }}$

Setia Budhi Wilardjo, VALUE ADDED, Vol.3, No.1, Merancang Strategi Pemasaran Untuk Pemimpin, Penantang, Pengikut, dan Perelung Pasar, September $2006 \pm$ Pebruari 2007 http://jurnal.unimus.ac.id

Among Makarti, Vol.4 No.7, Juli 2011, Analisis Faktor Untuk Mengetahui Efektivitas Strategi Me Too Sebagai Strategi Bersaing Perusahaan (studi kasus pada produk sm VIT C 1000 PT. Sido Muncul) oleh Yanuar Surya Putra

Sumber Artikel : Merancang Strategi Pemasaran Untuk Pemimpin, Penantang, Pengikut, dan Perelung Pasar oleh Setia Budhi Wilardjo, VALUE ADDED, Vol.3, No.1, September $2006 \pm$ Pebruari 2007 http://jurnal.unimus.ac.id

Jurnal Ilmiah Niagara Vol. IX No. 1, Juni 2017, strategi pemasaran dalam persaingan dunia usaha, Suhandi, Ilmu Administrasi Niaga Sekolah Tinggi Ilmu Administrasi Banten. 
Cynthia Yulita Wardayanti. Staf pengajar Fakultas Ekonomi, Universitas Kristen Petra, Surabaya, Jurnal Manajemen Pemasaran, Vol. 1, No. 2, Oktober 2006: Analisis Pengaruh Pioneer- Status Sebuah Merek Terhadap Sikap Konsumen Dalam Kategori Produk Vitamin C $500 \mathrm{mg}$.

Sudiman, Program Studi Magister Manajemen Universitas Tarumanagara, Jurnal Manajemen Bisnis dan Kewirausahaan/Volume 02/No.3/Mei-2018, Strategi Pemasaran PT X dalam Meningkatkan Penjualan oleh.

James Rianto Situmorang, Pemasaran Relung (Niche Marketing) Sebagai Strategi Membidik Pasar Yang Lebih Kecil.

Laili Savitri Noor, Derriawan, Soebagyo, Fakultas Ekonomi dan Bisnis, Universitas Pancasila, Jurnal Riset Bisnis Vol 2 (1) (Oktober 2018), Inovasi UMKM Boga Tradisional Dalam Mencapai Keunggulan Bersaing.

Farham H.M. Saleh, Fakultas Teknologi Industri, Universitas Islam Indonesia, TEKNOIN, Vol. 10, No. 1, Maret 2005 ISSN 0853-8697, Model Ekspansi Kapasitas Yang Mempertimbangkan Persaingan Duopoli Dan Inovasi Teknologi Untuk Horison Perencanaan Terbatas Studi Kasus: Jaringan Akses Kabel Telekomunikasi.

Michael Adiwijaya, Fakultas Ekonomi, Universitas Kristen Petra Surabaya Jurnal Manajemen Pemasaran, Vol. 2, No. 2, Oktober 2007: Analisa Strategi Reposisi Merek Dalam Persaingan Pasar.

Rusindiyanto Teknik Industri FTI-UPNV Jatim ejournal.upnjatim.ac.id/index.php/ tekmapro/article/view/308, Prediksi Pangsa Pasar Produk Deterjen Merek Rinso Dengan Metode Markov Chain Guna Menentukan Strategi Pemasaran.

Yayuk Sri Rahayu, Jurusan Manajemen, UIN Maulana Malik Ibrahim Malang, Analisis Posisi Bersaing Untuk Menentukanstrategi Pemasaran UMKM Di Kota Malang.

https://dindingkota.co/strategi-penantang-pasar/.strategi-penantang-pasar, revolutionjher Bisnis, Ekonomi, Strategi .

(Lembaga Survei ICONESIA), Strategi Pengikut Pasar, http://iconesiaisp.blogspot.com/2015/06/strategi-pengikut-pasar.html

http://kerajaanberbagi.blogspot.com/2012/06/strategi-pemasaran-dalam-berbagai.html.

Strategi Pemasaran Dalam Berbagai Posisi Persaingan.

https://www.topbrand-award.com/en/2019/12/brand-follower-2/ Brand Follower!23 December 2019

http://kerajaanberbagi.blogspot.com/2012/06/strategi-pemasaran-dalam-berbagai.html.

Strategi Pemasaran Dalam Berbagai Posisi Persaingan,

https://www.glngirwn.com/blog/strategi-ceruk-pasar/ Strategi Bisnis Ceruk Pasar (Niche Market). Dipublikasikan oleh Gilang Irwan pada 15 Maret 2020. 
https://tulisanterkini.com/artikel/artikel-ilmiah/8382-strategi-penggarap-relungpasar.html. Strategi Penggarap Relung Pasar

https://koinworks.com/blog/analisis-kompetitor-sebelum-memilih-bisnis/Analisis Kompetitor Sebelum Memilih Bisnis

https://ukirama.com/blogs/berikut-4-tipe-kompetisi-persaingan-dalam-bisnis-danstrategimemenangkannya 4 Tipe Kompetisi (Persaingan) dalam Bisnis dan Strategi Memenangkannya By Martina, 19 Februari 2020

https://www.jurnal.id/id/blog/pasar-persaingan-sempurna-dan-pasar-persaingantidaksempurna-apa-perbedaannya/ Pasar Persaingan Sempurna dan Pasar Persaingan Tidak Sempurna, Apa Bedanya? 